everyone involved in counselling them has to be sensitive to their beliefs and adherence to Islam.

To our knowledge, HD has not been previously recorded in Saudi Arabia, nor in Afghanistan. Although European ancestry was not reported in any family, the disease gene could well have been introduced to them in the last century by foreigners visiting Red Sea or Arabian Gulf ports and, in the case of Afghanistan, travelling along traditional trade routes. Studies have shown that even the most isolated population affected by HD might have had European visitors in previous centuries. ${ }^{56}$ At present, the prevalence of $\mathrm{HD}$ in this population cannot be estimated, but it is likely to be comparatively low.

E M SCRIMGEOUR $S$ A TAHOON T H ZAWAWI Department of Medicine, National Guard
King Khalid Hospital, and the Neurology Department, Drs Erfan and Bagedo Hospital,
feddah 21423, Saudi Arabia

1 Hayden MR. Huntington's chorea. Berlin: Springer-Verlag, 1981 .

2 Harper PS. Huntington's disease. London: W B Saunders, 1991.

3 Stober T, Wussow W, Schimrigk K. Bicaudate diameter - the most specific CT parameter in the diagnosis of Huntington's disease. Neuroradiology 1984;26:25-8

4 Simmons JT, Pastakia B, Chase TN, Shults CW. Magnetic resonance imaging in Huntington's disease. AFNR 1986;7:25-8.

5 Scrimgeour EM. Huntington's disease in Tanzania. F Med Genet 1981;18:200-3.

6 Scrimgeour EM. Possible introduction of Huntington's chorea into Pacific islands by New England whalemen. Am f Med Genet 1983;15: 607-13.

\section{The Prader-Willi-like phenotype in fragile $X$ patients: a designation facilitating clinical (and molecular) differential diagnosis}

We thank Gillessen-Kaesbach and Horsthemke ${ }^{1}$ for their comment on our paper "Clinical and molecular studies in fragile (X) patients with a Prader-Willi-like phenotype" in the March 1994 issue. The use of "like" syndromic designations generally invokes discussion. We nevertheless chose to describe this rare phenotype of the fragile (X) syndrome in direct comparison with the PraderWilli syndrome (PWS). The eight fragile (X) patients described in our paper showed a special subphenotype consisting of mental retardation, a full, round face, truncal obesity, hypogenitalism, small, broad hands and feet (all prominent PWS symptoms), and regional skin hyperpigmentation. Moreover, they lacked major features of the Martin-Bell phenotype described in the majority of fragile (X) patients: a long face with large everted ears and megalotestes. Therefore the suggestion by Gillessen-Kaesbach and Horsthemke that these eight patients are just obese fragile (X) patients would be an insufficient clinical description of this special subphenotype. Considering the erroneous clinical diagnosis of PWS in two patients, the (partial) resemblance to classical PWS, and the necessity for a recognisable name for this special subphenotype we suggested the name "Prader-Willi-like". We hope that this will make clinicians aware of the need for performing DNA analysis for both chromosome $15 q$ abnormalities and the FMR-1 gene mutations in the mentally retarded patients presenting with either the Prader-Willi syndrome or the Prader-Willi-like subphenotype of the fragile (X) syndrome.

BERT B A DE VRIES MARTINUS F NIERMEIJER Department of Clinical Genetics, University Hospital Dijkzigt, Erasmus Universit Dr Molewaterplein 40 3015 GD Rotterdam The Netherlands.

1 Gillessen-Kaesbach G, Horsthemke B. Clinical and molecular studies in fragile $\mathrm{X}$ patients with a Prader-Willi-like phenotype. $₹$ Med Genet 1994;31:260-1.

2 De Vries BBA, Fryns JP, Butler MG, et al. Clinical and molecular studies in fragile $X$ patients with and molecular studies in fragile $\mathrm{X}$ patients with 1993;30:761-6.

\section{Arthrogryposis multiplex congenita, renal dysfunction, and cholestasis syndrome}

We read with interest the article by Horslen et $a l^{1}$ "Liver histology in the arthrogryposis multiplex congenita, renal dysfunction, and cholestasis (ARC) syndrome: report of three new cases and review". We would like to comment on the possibility of variation of histological findings in the liver within a single syndrome of arthrogryposis multiplex congenita, cholestatic liver disease, and renal impairment, or the existence of two separate conditions.

Whenever paucity of intrahepatic bile ducts was seen on hepatic histology, patients died between the ages of 3 months 2 weeks and 7 months. ${ }^{1-3}$ However, when lipofuscin deposition was present without paucity of intrahepatic bile ducts, patients always died before they were 3 months 2 weeks old. ${ }^{4-6}$ As it is unlikely that paucity of intrahepatic bile ducts could resolve, and as lipofuscin deposition only, whenever present, was always seen at the time of death, ${ }^{4-6}$ the possibility that the two histological features are different stages in the evolution of the disease can be discarded. However, the different hepatic histologies may be two non-specific changes resulting from the same insult, as was suggested by the presence of features compatible with both groups in one patient. ${ }^{1}$

We propose that the lipofuscin deposition occurs only when the liver is more severely affected and this would imply a worse prognosis. As there are two sibships where the first patients died when they were more than 4 months old and the younger affected brothers when they were less than 3 months old, ${ }^{13}$ we would suggest that the former had paucity of intrahepatic bile ducts and the latter had lipofuscin deposition. Unfortunately, in only one of the four patients were hepatic histological features studied ${ }^{3}$ but the result agrees with our hypothesis.

If the different clinical outcomes in the same sibship result from different hepatic histology, this would support the suggestion that different histological findings are nothing more than variation within a single syndrome. However, this remains an open question until the two are reported in the same sibship.

JORGE M SARAIVA
HENRIQUE C MOTA
Hospital Pediátrico,
Avenida Bissaya Barreto,
3000 Coimbra,
Portugal.

1 Horslen SP, Quarrell OWJ, Tanner MS. Liver histology in the arthrogryposis multiplex congenita, renal dysfunction, and cholestasis (ARC) syndrome: report of three new cases and review. $₹$ Med Genet 1994;31:62-4.

2 Lutz-Richner AR, Landolt RF. Familiare Gallengangsmissbildungen mit tubularer $\mathrm{Ni}$ lengangsmissbildungen mit tubularer $\mathrm{Ni}$ erenin 12 .

3 Mikati MA, Barakat AY, Sulh HB, Der Kaloustian VM. Renal tubular insufficiency, cholestatic jaundice and multiple congenital anomalies a new multisystem syndrome. Helv Paediatr Acta 1984;39:463-71.

4 Nezelof C, Dupart MC, Jaubert F, Eliachar E. A lethal familial syndrome associating arthrogryposis multiplex congenita, renal dysfunction, and a cholestatic and pigmentary liver disease. $\mathcal{F}$ Pediatr 1979;94:258-60.

5 Di Rocco M, Reboa E, Barabino A, et al. Arthrogryposis, cholestatic pigmentary liver disease and renal dysfunction: report of a second family. Am $₹$ Med Genet 1990;37:237-40.

6 Saraiva JM, Lemos C, Gonçalves I, Carneiro F, Mota HC. Arthrogryposis multiplex congenita with renal and hepatic abnormalities in a fewale infant. $\mathcal{f}$ Pediatr 1990;117:761-3. 